\title{
АНГЛИСКИТЕ ПРЕВОДНИ ЕКВИВАЛЕНТИ НА МАКЕДОНСКИОТ МОЖЕН НАЧИН СО ПРАГМАТИЧКА ФУНКЦИЈА
}

\author{
Анастасија Апостоловска \\ Училиште за странски јазици „PiccadillyS“, Скопје \\ anastasija.apostolovska1@gmail.com
}

Во оваа статија се претставуваат резултатите од истражувањето на англиските преводни еквиваленти на би-конструкцијата во прагматичка функција. Биконструкцијата функционира како експонент на можниот начин во македонскиот јазик за изразување хипотетичност и желбеност. За разлика од англискиот јазик, каде што овие значења се кодираат со модални глаголи, во македонскиот јазик $б u$-конструкцијата се гради и од модални и од полнозначни глаголи. Надвор од условните реченици, формите на можниот начин може да вршат и определена прагматичка функција поврзана со учтивост и ублажување на исказот. Во истражувањето се испитува во која форма почесто се јавува можниот начин во оваа функција и дали типот на глаголот (ползоначен или модален) во би-конструкцијата има влијание врз изборот на преводниот еквивалент. Резултатите покажаа дека можниот начин почесто се јавува со модален глагол во својот состав кога врши определена прагматичка функција. Анализата ја потврди хипотезата дека во контексти во кои би-конструкцијата врши прагматичка функција најчест преводен еквивалент е англискиот модален глагол would. Исто така, се покажа дека македонските модални глаголи во биконструкцијата условуваат употреба на одреден англиски модален глагол: така сака во можен начин се преведува со would, може со could, а mреба co should.

Клучни зборови: модалност, можен начин, модални глаголи, прагматичка функција, учтивост 


\title{
ENGLISH TRANSLATIONAL EQUIVALENTS OF THE MACEDONIAN POTENTIAL MOOD WITH PRAGMATIC FUNCTION
}

\author{
Aastasija Apostolovska \\ PiccadillyS Language School, Skopje \\ anastasija.apostolovska1@gmail.com
}

This paper presents the results of the investigation of the English equivalents of the $b i$-construction used in pragmatic functions. The $b i$-construction in Macedonian is the main marker of the potential mood encoding hypotheticality and volition. Unlike English, which employs modal verbs to render these meanings, the $b i$-construction recruits both modal and lexical verbs in its structure. In non-conditional uses, potential mood forms may perform a range of pragmatic functions related to politeness and hedging. The goal of the investigation is to determine whether the pragmatic function tends to be performed by bi-constructionc based on modal or lexical verbs and whether this influences the choice of the translational equivalent in English. The results show that potential mood $b i$-constructions containing a modal verb are more frequent. The analysis confirmed the hypothesis that pragmatically used bi-constructions tend to be translated with the modal verb would. Moreover, there seems to exist a strong semantic correlation between the $b i$-construction based on a particular modal verb and its English equivalent: thus saka chooses would, može - could, and treba-should.

Keywords: modality, potential mood, modal verbs, pragmatic function, politeness 


\section{1 Вовед}

Овој труд обработува тема од областа на модалноста, со фокус на биконструкцијата (би + л-форма) која во македонскиот јазик е главен експонент на можниот начин. Таа конструкција може да се употреби како прагматичка стратегија за ублажување на категоричноста на исказот кога е употребена надвор од условната реченица. Целта на овој труд е да ги пронајде еквивалентите на можниот начин во англискиот јазик употребени во истата функција. За да ја постигнеме поставената цел, спроведовме истражување на англиските преводни еквиваленти на македонската би-конструкција со определена прагматичка функција. Забележавме дека како преводни еквиваленти се јавуваат англиските модални глаголи. Со истражувањето сакаме да го утврдиме најчестиот англиски еквивалент на можниот начин и да ја провериме хипотезата дека изборот на преводниот еквивалент (односно кој модалниот глагол ќе се употреби) зависи од тоа дали би-конструкцијата со прагматичка функција се јавува со или без модален глагол во својот состав.

Потребата за едно вакво истражување произлезе од недостигот на подлабоки контрастивни македонско-англиски истражувања во оваа област. Исто така, сметаме дека анализата на преводните еквиваленти на биконструкцијата во прагматичка функција ќе придонесе за подлабоко разбирање на нејзината полисемија.

$Б u$-конструкцијата во македонскиот јазик функционира како граматикализиран (можен) начин (Lunt 1952; Kramer 1986; Hacking 1998, Lindstedt 2010; Конески Б. 1987; Конески К. 1990; Гочкова 1990; МиноваЃуркова 2000; Митковска 2018; Бужаровска 2018). Категоријата начин е граматичко средство со кое се изразува сематичката категорија модалност. Со модалноста се изразува односот на говорителот кон реалноста (Palmer 2001; Quirk et al. 1985; Huddleston and Pullum 2002), за разлика од немодализираните конструкции кои го предаваат настанот како реалност (Downing and Locke 2006).

Можниот начин во македонскиот јазик може да биде употребен во рамките на условната реченица, но и надвор од неа. Кога тој е употребен надвор од условната реченица, може да има три функции: да означува хипотетичко дејство, да означува желба да се направи нешто и да ја ублажува категоричноста на изразот (т.н. прагматичка функција). Функцијата на можниот начин зависи од контекстот, како и од синтаксичката конструкција во која се јавува: со полнозначен глагол како во пример (1) или со модален глагол (тука се вклучени и модализираните полнозначни глаголи, како што е глаголот сака). Претпоставуваме дека прагматичката функција на можниот начин повеќе доаѓa до израз кога тој е употребен со модален глагол, како во 
пример (2), и очекуваме дека ќе има повеќе примери во чиј состав ќе има модален глагол во можен начин.

(1) Би дошол денес.

(полнозначен глагол употребен во можен начин, само контекстот разјаснува дали станува збор за хипотетичко дејство - би можел $\partial а$ дојдам или желба - би сакал да дојдам)

(2) Би сакал / Би можел / Би требало да дојдам денес.

(во комбинација со деонтички модален глагол повеќе се пројавува прагматичката функција)

Нашите претпоставки во однос на можниот начин употребен во комбинација со модален глагол се следните: Кога модалните глаголи може, треба и сака се употребени во можен начин, целата конструкција се користи за да се ублажи наметнувањето. Модалниот глагол може употребен во можен начин има и епистемичко (3) и деонтичко значење (4) зависно од говорниот чин.

(3) $\quad$ Утре би можело да врне. (претпоставка)

(4) $\quad$ Утре биможеле да одиме. (предлог)

Во однос на преводните еквиваленти, се очекува дека англиските модални глаголи would, could, should и might ќе се јават како најчест еквивалент бидејќи сите тие може да изразат учтивост и несигурност (Quirk et al.1985; Downing and Locke 2006; Huddleston and Pullum 2002), со почеста употреба на would.

\section{2 Теориска рамка}

\section{1 Употреба на македонскиот можен начин надвор од условните реченици}

Во однос на употребата на македонскиот можен начин надвор од составот на условните реченици ја следиме поделбата направена од Митковска (2018). Таа тврди дека иако употребата на можниот начин во состав на условните реченици се смета за типична и е најмногу испитувана, анализата базирана врз квантификација на податоци покажува дека можниот начин почесто се јавува во други синтаксички структури, а не како дел од условни реченици. Во продолжение следува преглед на трите типа на употреба на формите на 
можниот начин (надвор од условни реченици) кои ги разликува Митковска (2018): хипотетичко значење, желба и прагматичка функција.

\subsection{1 Хипотетичко значење}

Хипотетичкото значење е основното, прототипско значење на можниот начин. Во контекстите во кои можниот начин има хипотетичко значење, тој се употребува за да изрази „претпоставена, евентуална можност при што не изразува глаголско дејство коешто вистински се случува во сегашноста, минатото или иднината, туку со него само се потенцира можноста, дека едно дејство може или можело да се исполни“ (Митковска 2018).

(5) Изразот 'bogatyetoni' би се превел со „,полни мрежи“1...

Во оваа функција можниот начин може да се употреби за да изрази препоставка или реакција на некоја ситуација која не е изразена со условна реченица, туку со некоја поинаква лексичка или синтаксичка конструкција (Митковска 2018: 107).

(6) E, зар би го сторил ти тоа?

\subsection{2 Желба}

Една од позастапените употреби на формите на можниот начин во некои народни говори е за изразување клетви и благослови (Конески Б. 1987), односно $б u$-конструкцијата се употребува во оптативна функција. За стандардниот јазик Митковска (2018) вели дека можниот начин се јавува во реченици кои имаат експресивно-желбена нијанса. Во примерите што таа ги анализира желбата често експлицитно е изразена со глаголот сака (7), а поретко е изразена имплицитно (8) кога се преклопува со значење на намера или има експресивна функција.

(7) По можност, би сакала да постирате и фотографии од ваши сплетени дела.

(8) Ex, кога само би можела да го избегнам тој поглед барем еднаш.

\footnotetext{
${ }^{1}$ Примерот кај Митковска е преземен од Hausman, Klaus (1956: 32) Der Potential im Mazedonischen. Dissertation zur Erlangung des Doktorgrades der Philosophischen Fakultet der Georg August Universität zu Göttingen, Göttingen.
} 


\subsection{3 Прагматичка функција}

Бидејќи можниот начин се употребува за смекнување на категоричноста на исказот, тој „се користи како прагматичка стратегија за 'заштита на лицето'“ (Митковска 2018: 108). Поимот лище, Јул (Yule 1996) го дефинира како слика која индивидуата ја проектира за себе за јавноста. ${ }^{2}$ Според него, овој поим „се однесува на емоционалното и социјалното значење на сопствено јас што сите луѓe го имаат и очекуваат останатите да го препознаат“ (Yule 1996: 60). Употребата на јазични стратегии и јазични функции кои се несоодветни може да доведе до загрозување на лицето на говорителот или на неговиот соговорник, па оттаму и до прекин во комуникацијата. Доколку говорителот каже нешто што би ги загрозило очекувањата на соговорникот дека неговото лице ќe се почитува, тоа се смета за чин кој го загрозува лицето ${ }^{3}$ (Yule 1996: 61). Бидејќи лицето може да биде повредено, говорителите „се стремат да ги избегнуваат овие говорни чинови, или применуваат стратегии со кои би ја свеле заканата на минимум“" (Brown and Levinson 1987: 68). Митковска (2018), следејќи ја Крамер (Kramer 1986), смета дека македонскиот можен начин ја шири својата употреба токму во оваа функција.

Во оваа функција се користат следниве изрази (преземени од Конески, К. 1990:117): би ви дал еден совет..., јас (не) би рекол/рекла..., кој би рекол..., би било добро да..., не би штетело ако... И самиот Конески К. во својата категоризација, всушност, ја издвојува прагматичката функција на можниот начин, но не го употребува тој термин, туку тој вели дека можниот начин може да се употреби и за „стилско нијансирање во однос на категоричноста на исказот“ (Конески, К. 1990: 218).

Се смета дека овие изрази се навлезени во македонскиот стандарден јазик по литературен пат, а во првите децении од стандардизацијата станале особеност на разговорниот јазик од повисок стил. Можниот начин во оваа функција често се јавува и со модални глаголи, како сака, смее, може, треба. Овие глаголи се употребуваат „како ублажувачи во говорните чинови за замолување, совет, извинување и слично, па со можниот начин се добива уште еден повисок степен на смекнување. Тие се користат и како „стратегија за ненаметнување“ (Митковска 2018: 109).

Би можела да му помогнеш на Марко.

Во својата анализа Митковска (2018: 110) наведува изрази со експлицитна употреба, кои може да ја вршат функцијата и сами по себе, без би, но и изрази со имплицитна функција во кои улогата на би е од суштинско значење за значењето на говорниот чин. За првите (10), би само дополнително ја маркира

\footnotetext{
${ }^{2}$ Англ. "the public self-image of a person" (Yule 1996).

3 Англ. "face threatening act" (Yule 1996: 61).
} 
функцијата на давање предлог или совет и има само прагматичка функција на учтивост, додека кај вторите, имплицитните (11), би е носител на функцијата учтивост (наместо категоричното сакам).

(10) Би требало малку да се запознаеш и со другите за да не треснуваш глупости како пред малку, ако не за повекее.

(11) Би ја пофалил администрацијата за испробување на повеке начини да го смени текот на форумот.

\section{2 Модалните глаголи во англискиот јазик}

Главно средство за изразување на модалност во англискиот јазик се модалните глаголи (Quirk et al. 1985; Downing and Locke 2006; Huddleston and Pullum 2002). Овие глаголи се граматикализирале за модалната функција и при тоа ги изгубиле граматичките категории лице и број, како и формалните дистинкции по семантичките категории време, вид, залог.

Бидејќи во овој труд бараме англиски еквиваленти на македонскиот можен начин во ситуации кога тој се употребува со определена прагматичка функција, ќе се посветиме повеќе на англиските модални глаголи would, could, should и might кои, исто така, може да бидат употребени со определена прагматичка функција.

\subsubsection{Would}

Прегледот на модалните глаголи во англискиот јазик го започнуваме со модалниот глагол would бидејќи токму тој е очекуваниот еквивалент на македонскиот можен начин.

Квирк и др. (Quirk et al. 1985: 233) го сметаат кодирањето на учтивоста за специјализирана функција на would. Оваа употреба тие ја нарекуваат „ублажено изразување на волја во учтиви барања“.

(12) Would you lend me a dollar?

'Би ми позајмил ли еден долар?'

(13) I'd be grateful if someone would hold the door open.

'Би бил благодарен кога некој би ја држел вратата отворена.'

\footnotetext{
${ }^{4}$ Англ. "tentative volition in polite requests" (Quirk et al. 1985: 233).
} 
Хаделстон и Пулам (Huddleston and Pullum 2002:200) го потенцираат значењето на колебливост кое овој модален глагол може да го изрази, и велат дека would носи значење на несигурност, ненаметливост, љубезност и слично.

(14) Would you tell them we're here.

'Би можеле ли да им кажете дека сме тука?'

\subsubsection{Could}

Според Квирк и др. (Quirk et al. 1985: 221, 222) овој модален глагол има три главни значења. Едно од тие значења е значењето на можност, за кое тие додаваат дека со употребата на could (наместо can) се овозможува поголем степен на учтивост.

(15) Your children could help me move these chairs.

'Твоите/Вашите деца би можеле да ми помогнат да ги преместам столчињава.'

Тие додаваат дека доколку исказот се претвори во прашање, предлогот се менува во учтиво барање (Quirk et al. 1985: 222).

(16) Could you (please) check these figures?

'Би можеле ли да ги проверите цифриве (Ве молам)?'

Понатаму тие (Quirk et al. 1985: 233) ги наведуваат и следниве значења на could: некатегоричност во учтиви барања (17) и во изразување на можност. Тука разликуваат две ситуации: изразување на мислење (18) и изразување учтиви наредби и молби (19).

(17) Could I see your driving licence?

'Може ли да ја видам Вашата возачка дозвола?'

(18) There could be something wrong with the light switch.

'Би можело да има некој проблем со прекинувачот.'

(19) Could you (please) open the door?

'Може ли/Би можеле ли да ја отворите вратата (Ве молам)?'

\subsubsection{Should}

Според Квирк и др. (Quirk et al. 1985: 227), овој модален глагол може да се употреби за да искаже обврска без наметнување. 
(20) The floor should be washed at least once a week.

'Подот треба да се исчисти барем еднаш неделно.'

Истата употреба ја наведуваат и Даунинг и Лок (Downing and Locke 2006: 383). Хаделстон и Пулам (Huddleston and Pullum 2002: 186, 187) сметаат дека основното значење на овој модален глагол е деонтичко (за изразување совет/препорака, критика за нешто што не се актуализирало во комбинација со перфектен инфинитив и индиректни директиви), а во продолжение го разгледуваат и мандативното 5 значење на should.

It is desirable that he should be told.

'Пожелно е да му се каже.'

\subsubsection{Might}

Квирк и др. (Quirk et al. 1985: 223) го разгледуваат модалниот глагол might заедно со модалниот глагол тау и велат дека тие се употребуваат за изразување дозвола која е дадена од страна на говорителот. Тие додаваат дека might се користи како понекатегорична, почутива варијанта на may. Меѓутоа, тие напоменуваат дека оваа употреба на might е ретка и застарена.

(22) Might I ask whether you are using the typewriter?

'Ке може/Би можеле ли да ми кажете дали ја користите машината за пишување?'

Во продолжение тие го наведуваат и изразот may/might (just) as well ('би можел и') кој има значење на зајадлива препорака или совет.

You might as well tell the truth (as continue to tell lies).

'Би можел и да ја кажеш вистината (наместо да продолжиш да лажеш).’

Овие препораки имаат негативно значење кое се потенцира со делреченица која изразува нереализиран, но очекуван настан и која најчесто се испушта.

Исто така, тие (Quirk et al. 1985: 233) ја набројуваат и т.н. специјализирана употреба на might, односно употребата на овој модален глагол за изразување на некатегоричност и учтивост. Некатегоричното изразување на дозвола се

\footnotetext{
${ }^{5}$ Мандативен субјунктив е категорија на сегашниот субјунктив. Според Квирк и др. (Quirk et al. 1985: 156), мандативниот субјунктив ја претставува најчестата употреба на субјунктивот и се употребува во зависни дел-реченици со сврзникот that. Овие дел-реченици се воведуваат во говорните чинови на барање, препорака, предлог, искажување намера итн.
} 
среќава во учтиви барања (24), а несигурна можност се среќава во искази кои изразуваат мислење (25).

(24) I wonder if I might borrow some coffee?

'Би можел ли да позајмам малку кафе?'

(25) Of course, I might be wrong.

'Се разбира, би можело/можно е да не сум во право.'

Употребата на овој модален глагол во индиректни барања е наведена и кај Даунинг и Лок (Downing and Locke 2006), а исто така и Хаделстон и Пулам (Huddleston and Pullum 2002).

\section{3 Анализа}

Примерите коишто влегуваат во составот на примерокот потребен за ова истражување се ексцерпирани од прозни литературни дела, односно романи и раскази, напишани од македонски автори. Примерокот за ова истражување се состои од примери кои се ексцерпирани од седум извори. ${ }^{6}$ Во примерокот се вклучени декларативни, прашални и одречни реченици, како прости така и сложени. Секоја би-конструкција се броеше одделно, што значи дека ако во една иста реченица има две би-конструкции, тие се бројат како два примери.

Еквивалентите на англиски јазик се ексцерпирани од соодветните преводи на англиски јазик на македонските дела. Вкупно беа ексцерпирани 343 македонски примери, од кои 335 се составени од би + л-форма, 7 се состојат од би во комбинација со $\partial a$-конструкција, а 1 пример во својот состав ја содржи копулата сум покрај $б u+$ л-форма. Фокусот на нашата анализа е првата конструкција, односно $б u+$ л-форма.

Анализата на примерите од примерокот е направена врз основа на трите употреби на формите на можниот начин надвор од условните реченици, односно хипотетичко-потенцијални, желбени и прагматички. Во ова истражување се претставени резултатите од анализата на примерите во кои можниот начин има прагматичка функција. Нив ги поделивме во две класи:

6 Андоновски, В. (2011). Папокот на светот. Скопје: НУБ; Антологија на македонскиот постмодернистички расказ (1990). Скопје: Наша Книга; Колбе, К. Б. (2011). Снегот во Казабланка. Скопје: НУБ; Македонски раскази (2011). Скопје: НУБ; Малески, В. (2011). Она што беше небо. Скопје: НУБ; Прокопиев, А. (2011). Избрани раскази. Скопје: НУБ; Солев, Д. (2011). Кратката пролет на Моно Самоников. Скопје: НУБ. 
- примери во кои експлицитно е употребен модален глагол (caкa, може, треба, мора), но со можниот начин се ублажува ставот на говорителот: Би сакала / Би морала/ Би требало / Би можела да си одам (наспроти Сакам / Морам / Треба / Можам да си одам)

- примери кои претставуваат говорни чинови на замолување и предложување без модален глагол: Дали би дошла со мене кај Влатко?

Од вкупниот број на примери во примерокот кои се состојат од би + лформа, во 76 примери можниот начин е употребен со определена прагматичка функција. Од нив, 27 примери се примери без модален глагол, а 49 примери се примери со модален глагол.

\section{1 Еквиваленти на примерите без модален глагол со прагматичка функција}

Кај овие примери најбројни еквиваленти се модалните глаголи (поточно модалниот глагол would) - од вкупно 27 примери во оваа група, 20 примери го имаат овој модален глагол за еквивалент. Останатите 7 примери се преведени со помош на друга преведувачка стратегија. Застапеноста на еквивалентите на примерите без модален глагол е претставена во табела 1.

Табела 1. Преводни еквиваленти на примерите без модален глагол со прагматичка функција

\begin{tabular}{|l|c|c|}
\hline \multicolumn{1}{|c|}{ Еквивалент } & Број на примери & $\begin{array}{c}\text { Процентуална } \\
\text { застапеност }\end{array}$ \\
\hline модални глаголи & 20 & $74.07 \%$ \\
\hline друго & 7 & $25.93 \%$ \\
\hline Вкупен број примери & 27 & $100 \%$ \\
\hline
\end{tabular}

\subsection{1 Модални глаголи}

Групата на модални глаголи како еквиваленти е најбројна кај примерите без модален глагол. Кај сите примери од оваа група (тоа се 20 примери) како еквивалент се јавува модалниот глагол would. Изборот на овој модален глагол како еквивалент се чини логичен ако ја земеме предвид неговата употреба за изразување учтивост, ненаметливост, љубезност (Quirk et al. 1985, Huddleston and Pullam 2002). За илустрација ги даваме примерите (26) и (27) со кои се искажува учтив, ненаметлив предлог. Не најдовме примери без модален глагол со прагматичка функција во кои како еквиваленти се јавуваат модалните глаголи could, should и might. 
(26) „Како би ти дошло едно патување?“"-рече уредникот одмерувајќи го ефектот од своите зборови на неговото лице и не престанувајки да се поигрува со пишалката. (Солев)

' "How would you feel about taking a trip?" the editor said, measuring the effect of his words on Mono's face, all the while playing with his pen.'

(27) А ти и твојот дуќан - тоа е нешто несигурно, нешто ни таму ни ваму, и би било најчесно од тебе да се определиш за работниците и да го поштуваш нивното дело. (Македонски раскази)

'And you and your shop - it's something uncertain, something in the middle, and it would be the most honest of you to side up with the workers and respect their work.'

\subsection{2 Друго}

Категоријата друго содржи 7 примери во кои преведувачите ја пренеле прагматичката функција на можниот начин со помош на други структури. Три од овие примери како еквивалент го имаат сегашното просто време (Present Simple Tense). Тие се прикажани во примерот (28). Во овој пример изразот не би рекол, со која се искажува учтиво несогласување, е преведен со I don't think so, за кој сметаме дека не го постигнува ублажувањето на изразот што се искажува со можниот начин.

Не би рекол, си рече Моно, не би рекол дека ти е доста. (Солев) 'I don't think so. I don't think you've had enough.'

Во 3 примери - (29), (30) и (31) можниот начин не е преведен, односно смислата на реченицата е предадена на поинаков начин. Во преводот на примерот (29) е употребена условна реченица if he had changed his mind што одговара на македонскато дали се премислил, а не на дали би ми ги продал uртежите. Меѓутоа, кога ќе се разгледа поширокиот контекст во кој е употребена реченицата станува јасно зошто е применета таква преведувачка стратегија.

Ниту во примерот (30) не е преведен можниот начин. Но, не можеме да кажеме дека со англиската реченица се губи значењето, односно дека читателите нема да можат да го сфатат предлогот. Напротив, употребена е конструкцијата how about која типично се употребува за изразување предлози.

Преводот на примерот (31) буквално значи со нетрпение го очекувам/едвај го чекам Вашето друштво. Значењето е слично, може да каже дури и посилно од тоа на оригиналната реченица. Објаснувањето можеби може да се најде во фактот дека преводниот еквивалент е реченична структура која често се 
користи во англискиот јазик, па преведувачот одлучил да ја искористи со цел да го доближи преводот до англиските читатели.

(29) Потоа те пратив тебе да го прашаш Давид, уште еднаш, дали би ми ги продал иртежите? (Колбе)

'I made you ask David, once again, if he had changed his mind?'

(30) Како би било, за снегот? (Колбе)

'How about, toasting to the snow?'

(31) Навистина, многу би ме радувало Вашето друштво. (Колбе)

'I am truly looking forward to your company.'

Минатото просто време се јавува како еквивалент во еден пример. Сметаме дека со преводниот еквивалент се губи смекнувањето на изразот што се постигнува со можниот начин во македонската реченица.

(32) Потем Фисот говореше глупости, како и обично; нѐ караше, ни се закануваше со укори, мавташе со прстот; и конечно, некаде пред крајот, рече дека би било добро да има што помасовен одглас на распишаниот конкурс за литературен состав на тема: „Перспективите на народната уметност денес. “ (Андоновски) 'The Athlete then droned on stupidly, as usual. He scolded us, threatened us with reprimands, and, eventually, toward the end of the class, said he expected an overwhelming response to an essay competition on the topic "The Perspective of the People's Arts Today."

\section{2 Еквиваленти на примерите со модален глагол со прагматичка функција}

Во нашиот примерок има 49 примери во кои се јавува модален глагол во можен начин кој врши определена прагматичка функција. Од овие примери, 36 примери ги имаат модалните глаголи како еквиваленти, 9 примери се преведени со помош на друга стратегија, а во 4 примери како еквиваленти се јавуваат други модални предикати (како на пример, be able, have). Застапеноста на еквивалентите на можниот начин со модален глагол со определена прагматичка функција е прикажана во табелата 2. 
Табела 2. Преводни еквиваленти на примерите со модален глагол со прагматичка функција

\begin{tabular}{|l|c|c|}
\hline \multicolumn{1}{|c|}{ Еквивалент } & Број на примери & \multicolumn{1}{c|}{$\begin{array}{c}\text { Процентуална } \\
\text { застапеност }\end{array}$} \\
\hline модални глаголи & 36 & $73.47 \%$ \\
\hline друго & 9 & $18.37 \%$ \\
\hline $\begin{array}{l}\text { други модални глаголи } \\
\text { и изрази }\end{array}$ & 4 & $8.16 \%$ \\
\hline Вкупен број примери & 49 & $100 \%$ \\
\hline
\end{tabular}

\subsection{1 Модални глаголи}

И во оваа група најбројни еквиваленти се модалните глаголи. Од нив, најзастапен е модалниот глагол would (во 22 примери), по него следува could (во 13 примери), а во 1 пример се среќава модалниот глагол should. Модалниот глагол might не се јавува како еквивалент на можниот начин со прагматичка функција. Застапеноста на секој модален глагол поединечно е прикажана во табела 3.

Табела 3. Застапеност на поединечните модални глаголи како еквиваленти на примерите со прагматичка функција кои имаат модален глагол во својот состав

\begin{tabular}{|c|c|c|c|}
\hline $\begin{array}{c}\text { Модални } \\
\text { глаголи }\end{array}$ & \multicolumn{2}{|c|}{ Број на примери } & $\begin{array}{c}\text { Процентуална } \\
\text { застапеност }\end{array}$ \\
\hline \multirow[t]{5}{*}{ would } & & 22 & \multirow{5}{*}{$61.11 \%$} \\
\hline & со модалниот глагол сака & 18 & \\
\hline & со модалниот глагол може & 2 & \\
\hline & со модалниот глагол треба & 1 & \\
\hline & со модалниот глагол мора & 1 & \\
\hline \multirow[t]{2}{*}{ could } & & 13 & \multirow[t]{2}{*}{$36.11 \%$} \\
\hline & со модалниот глагол може & 13 & \\
\hline \multirow[t]{2}{*}{ should } & & 1 & \multirow[t]{2}{*}{$2.78 \%$} \\
\hline & со модалниот глагол треба & 1 & \\
\hline $\begin{array}{l}\text { Вкупен број } \\
\text { примери }\end{array}$ & & 36 & $100 \%$ \\
\hline
\end{tabular}




\section{Would}

Модалниот глагол would ce среќава како еквивалент на најголем број примери со модален глагол. Тоа е очекувано бидејќ овој модален глагол се употребува за да изрази учтивост (Quirk et al. 1985: 233), која е од суштинско значење за остварување на прагматичката функција на можниот начин. Во 18 од овие примери во можен начин се јавува модалниот глагол сака. Во нив, со употребата на можниот начин се постигнува ублажување на наметнувањето (во предлози и молби). Такви се примерите (33) и (34).

(33) Би сакала да напишеш за нас нешто кусо и духовито, нешто како случките на мистер Бин. (Прокопиев)

'I would like you to write for us something short and funny, something similar to Mr. Bean's sketches.'

(34) По часот, ми пристапи Лучија; рече дека би сакала да разговара нешто со мене. (Андоновски)

'She approached me after class and said she would like to talk to me.'

Во два примери, (35) и (36), модалниот глагол would ce јавува како еквивалент на можниот начин во чиј состав е употребен модалниот глагол може. Во примерот (35) има два глаголи во можен начин, едниот е полнозначен, а другиот е модален. Двата се преведени со модалниот глагол would, иако може да се каже дека во преводот значењето на македонската реченица е малку променето: во оригиналот говорителот прашува дали госпоѓицата би можела по тренингот да дојде за да ја праша нешто, а во преводот се добива ситуација во која говорителот прашува дали госпоѓицата би му дозволила да ја праша нешто.

(35) Но јас би ве замолил да ја прамате гопоѓицата дали би можела, откако ке заврши со тренингот, да дојде да ја прашам нешто? (Андоновски)

'But I would like you to ask the lady whether after her practice she would let me ask her something.'

Во примерот (36) глаголот може употребен во можен начин е преведен со would + be able to. Модалниот перифрастичен предикат be able се употребува за да изрази способност (Huddleston and Pullum 2006: 208), а комбинацијата co would овозможува изразот да добие поголема учтивост.

(36) Не би можел да ти пишувам за ова, можеби ќе успеам да го фотокопирам текстот и да ти го испратам. (Антологија) 
'I wouldn't be able to write to you about it, perhaps I'll manage to photocopy the text and send it to you.'

Во еден пример, а тоа е (37), would се среќава како еквивалент на модалниот глагол треба употребен во можен начин. Меѓутоа, во преводот не е преведен изразот би требало, кој за сегашни ситуации најчесто има дедуктивно значење, но за идни ситуации може да има значење на претпоставка или може да е говорен чин на совет или предлог. Во овој случај употребата на би доведува до ублажување и дистанцирање. Англиската реченица има значење на би ти симнал капа.

(37) Би требало да ти симнам капа, но за жал, во моментов немам таков реквизит за оддавање почит. (Солев)

'I'd doff my hat, but unfortunately, at this precise moment, I'm not in the possession of the proper tools.'

Во еден пример (38), would е еквивалент на модалниот глагол мора употребен во можен начин. Во преводниот еквивалент модалниот глагол would ce комбинира со модалното have за да се пренесе значењето на македонскиот модален глагол кој е употребен во можен начин.

Јас нему можам да му објаснам зошто би морала да отсуствувам некое време. (Колбе)

'I can explain to him why I would have to leave for a while.'

\section{Could}

Во 13 примери во кои модален глагол е употребен во можен начин како еквивалент се појавува модалниот глагол could. Овој модален глагол, како и would, може да се употреби за да изрази учтивост и некатегоричност (Quirk et al. 1985: 233). Во сите овие примери модалниот глагол може се јавува во можен начин со што се постигнува смекнување на наметнувањето во предлозите. За илустрација ги даваме примерите (39) и (40).

(39) Би можел да бидеш малку поконкретен. (Прокопиев)

'However, you could be more precise.'

(40) Во паузата би можеле да изведеме една мала, лесна циркуска еквилибристичка точка. (Андоновски)

'During the intermission we could have a light and easy acrobatic balancing act.' 


\section{Should}

Во еден пример во кој модален глагол е употребен во можен начин како еквивалент се среќава модалниот глагол should. Се работи за пример во кој модалниот глагол треба се јавува во можен начин за да се ублажи наметнувањето при давање совет.

(41) Секому нешто му е однесено, секој би требало да чека. (Солев) 'Anyone that something has been taken from should be waiting.'

\subsection{2 Друго}

Во оваа категорија спаѓаат 9 примери. Во 4 примери (во кои модалниот глагол сака е употребен во можен начин) како еквиваленти се јавуваат глаголи што изразуваат желба да се направи нешто илустрирано во примерите (42) и (43).

(42) Јас немам - ѝ се обраќа тој со волчја љубезност - а би сакал да имам. (Македонски раскази)

'I am not - he addresses her with a wolf-like kindness - and I wished I had.'

(43) Но, исто така, му раскажа дека, поради сигурност и страв од собитие кобно, најпрвин би сакал да се отвори западната одаја, со преписот, умножението на записот, сочинето од отеи Мида и похрането таму пред триесет и четири лета Господови. (Андоновски)

'But he also told him that for the sake of safety and the fear of tragic consequences he preferred to have the western chamber opened, the one containing the copy of the inscription made by Father Mida and placed there ten years ago.'

Во 3 примери како еквивалент се јавува полнозначен глагол за желба кој формира субјунктивна конструкција со инфинитивен глагол претставено во примерите (44), (45) и (46).

(44) Ти би сакал одеднаш да засјаеш, а тоа е само сензачионална литература. (Солев)

'You want to glow immediately, and that's only possible of sensational literature.'

(45) Знаете, јас штотуку расчистив со една девојка, и би сакал да се оженам. (Андоновски)

'You know, I just came out of a relationship, and I want to get married.' 
(46) Би сакал коси да кубе, да пишти, да моли, да оптужува како пред четири години: „Куќава ќе ми ја затвориш! “ (Малески)

'I wish she would pull her hair, scream, bed, accuse, as she did four years ago: "You'll seal my house forever!"

Во 2 примери, (47) и (48), воопшто не е преведен модалниот глагол кој е употребен во можен начин со чија употреба се добива ублажување на наметнувањето при изразување на предлог или молба.

(47) Луција со задоволство ја прифати таа идеја, оти, рече, во сиенариото сосема ја заборавила изворната народна песна; $и$, второто нешто, рече Земанек, би требало да биде - паузата, бидејќ програмата е особено обемна и може да ја замори публиката. (Андоновски)

'Lucia readily accepted his suggestion and admitted that she forgot to put any folk songs in her program, though it was mostly "national" in scope. Zemanek added that he had one more suggestion: he said that the program, as proposed, would last too long and might become tiresome for the audience, so a break was needed, an intermission.'

(48) Таа беше првата од мочте пријателки овде, ито ја прашав дали би можела за кусо време да го надгледува празниот стан на моите. (Колбе)

'She was the first of my friends here whom I asked to temporarily keep an eye on my parents' empty apartment.'

\subsection{3 Други модални глаголи и изрази}

Во оваа група спаѓаат 4 примери, од кои во 2 како еквивалент се среќава модалниот глагол тау. Во останатите два се употребени модалниот глагол can и перифрастичниот предикат be supposed to.

\section{May}

Примерите (49) и (50) како еквивалент на модалниот глагол може во форма на можен начин го имаат модалниот глагол тау. Изборот на овој модален глагол како еквивалент е логичен бидејќи тау се употребува за учтиво давање или барање на дозвола (Quirk et al. 1985: 223).

(49) Извинете, би можел ли да добијам уште едно лимонадче? (Прокопиев)

'Excuse me, may I have another lemonade, please?' 
(50) Госпоѓ, дали би можел за миг да разговарам со Луција насамо, ве молам? (Андоновски)

'Ma'am, may I speak to Lucia alone for a moment, please?'

\section{Can}

Овој модален глагол се јавува како еквивалент во еден пример (51) во кој можниот начин е употребен во учтиво прашање. Сметаме дека овој пример не е добро преведен на англиски јазик бидејќи кога говорителот се обраќа на непозната личност не би требало да го користи модалниот глагол can. И самиот неправилен збороред во преводот укажува на ниско ниво на познавање на англискиот јазик на преведувачот.

(51) Знаете ли каде би можел да ја најдам продавницата за јужно овошје? (Прокопиев)

'Excuse me, lady; do you perhaps know where can I find the store for Southern Fruit?'

\section{Be supposed to}

Исто така, во еден пример еквивалентот на можниот начин е модалниот предикат be supposed to (52), кој може да има значење на неисполнета обврска и на нужност (Quirk et al.1985: 237). За споредба наведените автори ги даваат примерите Their team is supposed to be the best (треба да е, тоа е прифатеното мислење) и You were supposed to be here at nine (требаше да бидеш, неисполнета обврска). Во овој пример можниот начин придонесува за ублажување на значењето на обврска што го носи модалниот глагол треба, додека во преводот на англиски јазик ублажувањето не е пренесено.

Тој би требало да го обвинува авторитарниот режим на Советскиот сојуз, кој во детскиот дом, во кој го спасиле од Граѓанската војна, вовел толку строга дисииплина, која одредувала дури и кој што ќе студира. (Колбе)

'He is supposed to blame the authoritarian Soviet regime that incorporated strict discipline in the children's home that rescued him from the Civil War and determined who will study what.'

\section{4 Заклучок}

Врз основа на спроведената анализа, можеме да го заклучиме следното: кога можниот начин е употребен со определена прагматичка функција, тој почесто се јавува со модален глагол во својот состав отколку со полнозначен глагол. 
Ова нѐ води до заклучокот дека за да изврши одредена прагматичка функција, во најголем број случаи, потребно е можниот начин во својот состав да има модален глагол. Модалните глаголи кои се среќаваат употребени во можен начин во нашиот примерок се сака, може, треба и мора. Најбројни се примерите во кои глаголот сака се јавува во можен начин (во нашиот примерок наидовме на вкупно 25 примери со овој глагол), а следни се примерите со глаголот може (примерокот содржи вкупно 18 примери со овој глагол). Во 4 примери се јавува глаголот треба, а само во еден пример употребен е глаголот мора.

Во однос на преводните еквиваленти, како што и очекувавме, англискиот модален глагол would се јавува како најчест еквивалент на можниот начин во двете класи примери. (со и без модален глагол). Во примерите во кои модален глагол е употребен во можен начин, would најчесто се јавува како еквивалент на оние примери во кои се јавува македонскиот глагол сака. Англискиот модален глагол could се јавува како еквивалент на оние примери во кои македонскиот модален глагол може е употребен во можен начин, a should ce јавува како еквивалент на еден пример во кој во можен начин е употребен модалниот глагол треба. Наспроти очекувањата, англискиот модален глагол might не се јави како еквивалент во ниту еден пример. Според овие резултати, можеме да заклучиме дека изборот на преводните еквиваленти не е случаен: употребата на одреден македонски модален глагол во можен начин дефинитивно ја условува употребата на одреден англиски модален глагол како еквивалент. Како најчести преводни еквиваленти на примерите во кои можниот начин врши определена прагматичка функција се јавуваат модалните глаголи would и could.

Во врска со останатите преводни еквиваленти на можниот начин во прагматичка функција, можеме да заклучиме дека втори во однос на застапеноста се другите преводни стратегии што преведувачите ги употребуваат за да ја пренесат функцијата што ја изразува можниот начин. Тука спаѓаат послободни преводни еквиваленти, кои се адаптирани на контекстот и кои понекогаш не успеваат да го пренесат ублажувањето на тврдењето што се постигнува со можниот начин. Исклучок е само модалниот глагол тау, чија употреба како преводен еквивалент е сосема соодветна.

Се надеваме дека сознанијата од овој труд ќе придонесат за подлабоко разбирање на македонската би-конструкција, како и за нејзиното соодветно преведување на англиски јазик. Сепак, за да се добие целосна слика за полисемијата на можниот начин, сметаме дека би требало нашите резултати да се потврдат и со анализа на говорниот јазик.

\section{Библиографија}

Бужаровска, Е. (2018). Функцијата на би за изразување обусловени дејства во македонскиот јазик. Во 3. Тополињска (ур.). Статусот на модалната морфема 
би во македонскиот јазик и нејзините функционални еквиваленти во другите словенски и несловенски јазици, 25-48. Скопје: МАНУ.

Гочкова, Т. (1990). Конструкции со би во јазикот на Димитар Солев. Годишен зборник на Филолошкиот факултет на Универзитетот „Кирил и Методиј“, книга 16. Куманово: Просвета.

Конески, Б. (1987). Граматика на македонскиот јазик. Скопје: Култура.

Конески, К. (1990). Односот на глаголските конструкции со ќе и можниот начин. Во Конески, К. За македонскиот глагол. Скопје: Детска радост.

Минова-Гу уркова, Л. (2000). Синтакса на македонскиот стандарден јазик. Скопје: Магор.

Митковска, Л. (2018). Можниот начин надвор од условниот период во современиот македонски јазик. Во 3. Тополињска (ур.). Статусот на модалната морфема би во македонскиот јазик и нејзинте функционални еквиваленти во другите словенски и несловенски јазици , 97-118. Скопје: МАНУ.

Brown, P. and Levinson, S. (1987). Politeness: Some universals in language usage. Cambridge: Cambridge University Press.

Downing, A. and Locke, P. (2006). English grammar: A university course (2 ${ }^{\text {nd }}$ edn.). London/New York: Routledge.

Hacking, J. F. (1998). Coding the hypothetical: A comparative typology of Russian and Macedonian conditionals. Amsterdam: John Benjamins.

Huddleston, R. and Pullum, G. K. (2002). The Cambridge grammar of the English language. Cambridge: Cambridge University Press.

Kramer, C. E. (1986). Analytic modality in Macedonian. Munich: Verlag Otto Sagner.

Lunt, H. (1952). A grammar of the Macedonian literary language. Skopje.

Lindstedt, J. (2010). Mood in Bulgarian and Macedonian. In B. Rothstein and R. Thieroff (eds.). Mood in the languages of Europe, 409-422. Amsterdam: John Benjamins.

Palmer. F. R. (2001). Mood and modality. Cambridge: Cambridge University Press.

Quirk, R., Greenbaum, S., Leech, G. and Startvik, J. (1985). A comprehensive grammar of the English language. London: Longman.

Yule, G. (1996). Pragmatics. Oxford: Oxford University Press. 